\title{
The African Financial Development and Financial Inclusion Gaps
}

\author{
FRANKLIN ALLEN, ELENA CARLETTI, ROBERT CULL, JUN “QJ” QIAN, \\ LEMMA SENBET, AND PATRICIO VALENZUELA*
}

This version: September 2013

\begin{abstract}
This paper investigates the African financial development and financial inclusion gaps relative to other peer developing countries. Using a set of variables related to financial development and inclusion, we first estimate the gaps between African countries and other developing countries with similar degrees of economic development. Then, we explore the determinants of financial development and inclusion and find that population density appears to be considerably more important for financial development and inclusion in Africa than elsewhere. We then show evidence that a recent innovation in financial services, mobile banking, has helped to overcome infrastructural problems and improve financial access.
\end{abstract}

JEL CODES: G2; O1; R2.

KEY WORDS: Financial development, financial inclusion, development gaps, Africa

\footnotetext{
* Allen is from the University of Pennsylvania, Carletti is from Bocconi University, Cull is from the World Bank, Qian is from Boston College, Senbet is from University of Maryland, and Valenzuela is from the University of Chile. We are responsible for all the remaining errors.
} 


\section{Introduction}

Although most sub-Saharan African countries have undergone extensive financial sector reforms in the last two decades, their financial sectors remain under-developed, even relative to the standards of developing countries. Liquid liabilities and private credit in African financial sectors averaged below 40 and 25 percent of GDP, respectively, in 2011, substantially below that in other regions of the developing world (see Table 1). In terms of financial inclusion, the percentage of Sub-Saharan Africans older than 15, who had an account with or a loan from a formal financial institution, were about 25 and 5 percent, respectively, in 2011 (see Table 2). Only developing countries from the Middle East and North Africa exhibited similar patterns.

There is little academic research that addresses underperformance of the financial sector reforms in Africa and what could be improved. This paper is part of a new research agenda addressing key issues at the heart of African financial development and financial inclusion. We have three goals. First, we assess whether financial development and financial inclusion gaps exist in Africa, using other developing countries as a benchmark. We also assess whether any such gaps are closing over time. Second, we identify factors that have more pronounced impact on financial development in Africa than in other developing countries. Third, we document recent innovations and financial services, such as mobile banking, which can help overcome infrastructural deficiencies to improve financial access (see Table 3)

To calibrate the financial development and financial inclusion 'gaps' between Africa and other developing countries, we first analyze the determinants of financial development and financial inclusion in other developing countries (low and middle-income countries) via regression models based on prior research. We use the regression coefficients to generate predicted levels of financial development and financial inclusion for sub-Saharan African countries. We then compare those predicted levels with the actual levels of financial development in the African countries. We find that the majority of African countries have lower levels of financial development and financial inclusion than would be predicted based on their fundamentals. Those benchmarking regressions also indicate that population density is more strongly associated with financial development and financial inclusion in Africa than 
in other developing countries. If frequent interactions among firms, households, and investors are a necessary condition for business transactions, and hence financial development and financial inclusion, then our results are plausible in that many African countries have relatively scattered populations and poor roads.

In this analysis we focus on financial development and financial inclusion measures from 2007 to 2011, but our findings are similar to those from our previous research which is based on the narrower dimension of African financial development for the period 1990-2006 (Allen et al., forthcoming). In particular, the existence of development gaps and the importance of population density in explaining African financial development were also evident in the earlier period. When we broaden the dimension of African finance beyond the traditional banking sector development indicators, our evidence indicates that gaps exist in financial inclusion as well relative to other peer non-African low income countries. At the same time, the evidence presented here shows that the financial development gaps are closing somewhat, especially in terms of savings. Moreover, by expanding our indicators of financial development to include new measures of financial inclusion we offer a more nuanced account of the progress made so far and the challenges that remain.

Our paper, therefore, contributes to an emerging literature on the usage of financial services in Africa, which pays particular attention to financial product innovations and alternative delivery channels (for standard financial products). For example, our own recent research on Kenya shows how Equity Bank's branching expansion to underserved areas and a strategy to attract minority-speaking clients by communicating with them in their native tongue brought about substantial increases in the probability of having a bank account (5-10 percentage points relative to an initial level of $14 \%$ banked in 2006) and more modest increases in the share of Kenyans with formal loans (Allen et al., 2012).

Experimental studies based on randomized controlled trials (RCTs) show that female shopkeepers in rural Kenya (Dupas and Robinson, 2011) and tobacco farmers in Malawi (Brune et al., 2011) used commitment savings accounts that enabled them to credibly claim that they could not divert funds to outside demands to grow their businesses more rapidly than business owners in the control group. In the case of tobacco farmers, they also changed their inputs and production methods. 
Another area where Africa has seen substantial recent progress is electronic payments. Mtransfer systems facilitate financial transactions via mobile phones, allowing users to deposit and withdraw cash from an account that is accessible by mobile handset. Users can store value in the account and transfer value between users via text messages, menu commands, and personal identification numbers (Aker and Mbiti, 2010). The most famous of these systems is M-Pesa in Kenya. Launched in 2007 by the Kenyan mobile network operator, Safaricom, the mobile payments wallet had 15 million registered users by early 2012. Recent analyses show that M-Pesa use has brought about a substantial decline in the costs of sending transfers and a substantial increase in their volume (especially remittances), a greater likelihood of being formally banked, and decreased the use of informal savings mechanisms (Mbiti and Weil, 2011; Jack and Suri, 2010).

Another example comes from Niger, where an M-transfer system is providing a more costeffect means of implementing a cash transfer program to villages suffering from the effects of drought. Experimental evidence shows that the program substantially reduced the cost of distributing and obtaining the cash transfers (Aker et al., 2011). Households also used their transfers to purchase a more diverse set of goods, increased the diversity of their diets, depleted fewer assets, and grew a wider variety of crops (including marginal crops typically grown by women). Both the time savings for recipients of these M-transfers and the added security and privacy of electronic transfers are likely to be driving these effects.

In this paper, we look for confirmation of these trends by updating our financial development benchmarking analysis to a more recent period, and by expanding the set of dependent variables to include measures of financial inclusion based on surveys of users of financial services. In particular, having established population density as a key factor for financial development and inclusion in Africa, we explore whether innovations in financial services, such as mobile banking, have helped to overcome sparse populations and infrastructural problems and improve financial access.

To evaluate the use of mobile telephones in financial transactions, we run regressions on the determinants of the share of adults that use mobile phones to send money, receive money, and make payments. We run these regressions for all middle and low income countries, but we augment these specifications to include dummy variables by region. We find that, 
controlling for a large set of country-level variables, the use of mobile phones to send and receive money is significantly more prevalent in Sub-Saharan African countries than in the rest of the developing world. These results indicate that technological advances, such as mobile banking, have been an avenue to facilitate broader financial inclusion.

The remainder of the paper is organized as follows. Section 2 describes the empirical strategy and data. Section 3 reports the African financial development and financial inclusion gaps. Section 4 explores whether the determinants of financial development and inclusion are different in Africa than in the rest of the developing world. Section 5 provides evidence on the effects of mobile banking on usage of financial services, while Section 6 concludes.

\section{Empirical Strategy and Data}

The main objectives of this study are threefold. The first goal is to benchmark African financial development and financial inclusion relative to a set of variables that have been robustly associated with financial development in countries outside of Africa, especially in low and middle income countries. The second goal is to explore whether the determinants of financial development and inclusion in Africa are the same as those in the rest of the developing world. The final goal is to examine whether financial innovations, such as mobile banking, have helped to overcome the underdevelopment of financial markets and relative lack of financial inclusion in Africa. Below, we explain the methodology and data that we use in this paper to achieve our goals.

\subsection{Basic Determinants of Financial Development and Inclusion}

We employ regression analysis to examine the level and variation of financial development and financial inclusion across countries, relying on some of the same variables that have been used to study the links between financial development and growth (Levine, 2005). ${ }^{1}$ We include macroeconomic variables, such as inflation and real growth, and broad measures of institutional development. We stress from the outset that we are not necessarily estimating

\footnotetext{
1 As in other recent papers, we use these variables, including growth, to describe financial development (Cull and Effron, 2008; Cull, Senbet, and Sorge, 2005). By contrast, in the finance and growth literature, the financial indicators are among the explanatory variables used to explain growth.
} 
causal relationships. For ease of exposition, however, we refer to all explanatory variables as determinants of financial development throughout the paper.

The regression model for the expanded set of explanatory variables is:

$$
\begin{aligned}
& y_{i}=\alpha+\beta_{1} \text { Population }_{i}+\beta_{2} \text { Population Density }_{i}+\beta_{3} \text { Natural Resources }_{i} \\
& +\beta_{4} \text { Off shore Center }_{i}+\beta_{5} \text { GDP per capita } i+\beta_{6} \text { Growt }_{i}+\beta_{7} \text { Inflation }_{i} \\
& +\beta_{8} \text { KKM Index }{ }_{i}+\beta_{9} \text { Manufacturing } / G D P_{i}+\beta_{10} \text { Sec./Prim.enrollment }{ }_{i}+\varepsilon_{i} \text {. }
\end{aligned}
$$

where the dependent variable $\left(y_{i}\right)$ represents financial development and financial inclusion respectively. We briefly explain all our variables below. Appendix A reports the list of all the variables used in this study, their descriptions and sources.

We average our indicators of financial development and our explanatory variables over multiple years (from 2007 to 2011), as is customary in the literature on financial development and growth so as to reduce the influence of outliers. We therefore have only one observation per country. Because our goal is to describe a general picture of the factors that are robustly linked to financial development, however, we present below only the simplest cross-country regressions in which the financial indicators and explanatory variables are contemporaneous. For financial inclusion variables, the only available year is 2011. Therefore, we can only estimate cross-country regressions. Again, to reduce the influence of outliers, all of our explanatory variables are an average of the period 2007-2011.

\subsection{Financial Development Measures}

In our analysis we use two standard indicators of financial development, namely the ratio of liquid liabilities in the banking system to GDP and the ratio of credit to the private sector to GDP. The choice of these variables is based on the approach taken in Beck et al. (2008). Under this approach, the potential financial development indicators are ranked on the following criteria: (a) the directness of their linkages to welfare, (b) the goodness of fit of regressions that explain variation in them, (c) their coverage in terms of countries and years, and, (d) the degree to which an indicator is stable within a country from year to year, but varies substantially across countries. Moreover, these variables are robustly associated with long-run economic growth (Levine 2005; Levine, Loayza, and Beck, 2000). Our analysis is 
rooted in banking indicators because banks hold the vast majority of financial sector assets in Africa and other developing countries. ${ }^{2}$ The source of these variables is the World Bank Financial Development and Structure Dataset (Beck and Demirgüç-Kunt, 2009).

\subsection{Financial Inclusion Measures}

In this study, we employ five measures of financial inclusion. The first is the percentage of adults that have an account at a formal financial institution. The second is the percentage of adults that had a loan from a financial institution in the year prior to the survey. The last three variables are related to the use of mobile telephones in financial transactions. They are the percentage of adults using mobile telephones to send money, to receive money, and to pay bills. We use these variables to explore whether mobile banking has exhibited deeper penetration in Africa than elsewhere.

All variables related to financial inclusion are taken from the World Bank Global Financial Inclusion (Global Findex) Database, which measures how people in 148 countries save, borrow, make payments and manage risk. This database was recently released and therefore only covers the year 2011.

\subsection{Explanatory Variables}

In the choice of the explanatory variables for financial development and financial inclusion, we rely on previous studies, in particular those on the finance-growth nexus (e.g., Levine, 2005) and from other studies that analyze the determinants of financial development (e.g., Beck et. al, 2008; Cull and Effron, 2008). These studies regress indicators of financial development on a set of variables that describe the environment in which such development takes place, but that are exogenous to that process such as population size and density, natural resources and a dummy variable for offshore financial centers. They also include per capita income as an exogenous regressor, claiming that its effect on financial development is

\footnotetext{
${ }^{2}$ For most countries of Sub-Saharan countries, stock exchanges are just a recent phenomenon. The number of stock exchanges have, in fact, proliferated to over two dozen in the last decade. While this is an encourage outcome, the stock exchanges (except South Africa) are thin and malfunctioning although even on liquidity provision score things have improved (Senbet and Otchere, 2008). With more robust stock market development in Ethiopia it would be worth expanding the domain of financial development to include stock markets in future analyses.
} 
contemporaneous while the effect of financial development on income is lagged. We expand further the set of regressors by including macroeconomic variables and broad measures of institutional development. Below we briefly discuss the economic intuition underlying our explanatory variables:

Population: A larger population should spur financial development due to scale and networking effects that make provision of financial services more efficient in larger economies.

Population density: We measure population density by the number of residents per square kilometer. It should have a positive impact on financial development and financial inclusion in part because it is easier for financial institutions to accumulate savings when a higher number of potential depositors have easy access to them.

Natural Resources: An abundance of natural resources may have a negative effect on financial development and financial inclusion via the so-called "resource curse."” We measure the intensity of a country's reliance on natural resources by using a comprehensive approach that measures resource abundance based on trade indicators rather than solely on oil exports:

$$
\text { Natural Resources }=\sum_{k} \frac{\text { Exports }_{k}-\text { Imports }_{k}}{\text { Population ages } 15-64}
$$

Where $\mathrm{k} \in\{$ pretroleum, forest, tropical, animal, cereal, raw material\}. The key advantage of this approach is that this measure of net exports is available for most countries and, as shown by Lederman and Maloney (2008), is more closely linked to actual natural resource reserves than other trade-based endowment measures.

Offshore Centers: The financial sectors of offshore centers are typically much larger than their economies would otherwise warrant. We measure this effect with a dummy variable for offshore financial centers and we expect it to be positively related to financial development and financial inclusion.

\footnotetext{
${ }^{3}$ Sachs and Warner $(1995,2001)$ offer evidence that resource-rich developing countries have grown more slowly since 1960 than other developing countries.
} 
GDP Per Capita: Per capita income is expected to be positively linked to financial development and financial inclusion, because the volume and the sophistication of financial activities demanded is greater in richer countries and, on the supply side, richer economies can better exploit scale economies in the provision of financial services.

Growth: The effect of real growth on financial development is ambiguous. On the one hand, countries with rapid growth may be associated with greater financial development and financial inclusion. On the other hand, countries with higher levels of development, as reflected in GDP per capita, tend to have slower growth according to 'conditional convergence' (Levine and Renelt, 1992; Easterly and Levine, 1997). Because financial development is highly correlated with per capita income, real growth may be negatively correlated with our measures of financial development and inclusion.

Inflation: On the private credit side, inflation should slow financial development if it makes loan contracting over extended periods more difficult. Inflation could also have a dampening effect on liquid liabilities, making depositors more hesitant to place their savings in the formal financial system for fear of not being able to get them back quickly enough. Therefore, we expect the coefficient for inflation to be negative in our regressions.

KKM Index: We include in the regression the KKM Index, which is the measure of broad institutional development created by Kaufmann, Kraay, and Maztruzzi (2007). Institutional development has been found to foster financial development in developing countries (Cull and Effron, 2008), and thus we expect a positive coefficient for KKM in our regressions.

Manufacturing / GDP: We include the share of GDP generated by the manufacturing sector. Industrial sectors that are relatively more in need of finance tend to grow faster in countries with well-developed financial sectors (Rajan and Zingales, 1998). Manufacturing encompasses a broad variety of activities that tend to rely heavily on external finance so that we expect countries with a large manufacturing sector to have well-developed complementary financial institutions. We therefore expect a positive coefficient for manufacturing in our regressions. 
Secondary/Primary enrollment. Finally, we want to measure the impact of risk management on financial development. The idea is that a lack of capacity in risk management may be a deterrent to banking sector development and broader financial sector development. Because measuring financial capabilities across countries directly is not possible, we proxy risk management capability with the ratio of secondary to primary school enrollment and we expect its coefficient to be positive. Our argument is that risk management capability is fundamentally a question of human capital development and thus of talented financial people.

The summary statistics for all variables used in this study appear in Table 4. We divide our sample between middle and low income countries other than Sub-Saharan African countries. The table shows that the mean values for the financial development and financial inclusion indicators (except for mobile financial transactions) are uniformly lower in Africa than in the rest of the developing world. We also see some marked differences in the explanatory variables between Africa and the rest of the developing world (e.g., population and population density).

\section{The African Financial Development and Financial Inclusion Gaps}

To benchmark African financial development and financial inclusion, we estimate Equation (1) for countries outside Africa, which enables us to predict what African financial development and inclusion should be based on the experience of these other countries. Specifically, we first run the regressions excluding Sub-Saharan African countries, and we derive out-of-sample predictions for African financial development and inclusion. Then we compare these predictions with the actual levels of African financial development and inclusion to measure the gaps. Tables 5 and 6 present our models for low and middle income countries (excluding Sub-Sahara Africa).

The results for Equation (1) using our measures of financial development as the dependent variables are presented in Table 5. Columns 1 and 3 report our estimates for the specification with a limited set of regressors as a benchmark. All coefficients have the expected sign and some of them are statistically significant. GDP per capita and the Offshore Financial Center dummy variable are significantly positively associated with both 
indicators of financial development, and population density and natural resources are also significant in the private credit regression.

When we include macroeconomic, institutional, and other explanatory variables in Columns 2 and 4, the Offshore Financial Center variable is again positively associated with both liquid liabilities and private credit (as a percentage of the GDP). Inflation is negatively linked to liquid liabilities to GDP and Natural Resources is negatively related to private credit to GDP. Our proxy for the degree of institutional development, as represented by the KKM index, is positive and highly significant in the private credit to GDP regression. This result provides support for the notion that broad institutional development helps to foster financial development.

The results for Equation (1) using measures of financial inclusion as the dependent variables are presented in Table 6. Fewer variables are statistically significant. When we use the sample of non-African countries and the limited set of regressors as a benchmark, (see Columns 1 and 3), only GDP Per Capita is positively associated with the percentage of adults that have an account at a formal financial institution.

The expanded regression results are presented in Columns 2 and 4. The KKM Index is positively related to the percentage of adults that have an account at a formal financial institution. And, Growth is positively related to the percentage of people having a loan from a formal financial institution.

\subsection{Predicted Versus Actual African Financial Development and Financial Inclusion}

We now use the regression coefficients in Tables 5 and 6 to derive predicted levels of financial development and financial inclusion for each country in Africa. Again, we are not claiming that the relationships we find in these tables are causal. Rather, we are asking what the level of financial development and financial inclusion would be if the same relationships held in Africa as in the rest of the developing world. To the extent that predicted and actual levels of financial development and financial inclusion are similar, one can say that African financial development and financial inclusion are about what it should be. 
The top panel of Figure 1 shows that only eight of forty countries have levels of liquid liabilities to GDP that are at or above their predicted levels. Of these countries, only six exceed their predicted levels by a notable amount. Cape Verde (abbreviated as CPV in the figure) and Mauritius (MUS) exceed their predicted levels by a substantial amount, but neither of the two is particularly reflective of the African experience. The other countries with actual levels of liquid liabilities to GDP above their predicted levels are Kenya (KEN), Namibia (NAM), Gabon (GAB), and Guinea (GIN). The result on Kenya is somewhat expected as in recent years the country has witnessed a strong bank branch expansion. As noted, this expansion has coincided with the emergence of Equity Bank, a pioneering commercial bank that devised a banking service strategy targeting low income clients and traditionally under-served territories (Allen et al., 2012). Gabon and Guinea are huddled in the lower left hand corner of the figure where actual and predicted values are very low.

The bottom panel of Figure 1 shows that only eight of forty countries have levels of private credit to GDP that exceed their predicted levels by a notable margin: Gabon, Angola (AGO), Liberia (LBR), Nigeria (NGA), Namibia, Cape Verde, South Africa (ZAF) and Mauritius. Of those countries, Gabon, Angola, and Liberia are in the lower left hand corner of the figure where actual and predicted values are very low. We note that because the predicted values are based on linear regressions, they tend to be very near zero for countries clustered in the lower left corner of the private credit panel in Figure 1. The fact that their actual levels exceed zero by some small amount is little consolation. Moreover, Cape Verde, South Africa and Mauritius are not particularly representative of the African experience.

Although the majority of African countries have lower levels of financial development than predicted in Figure 1, we note that the typical gaps are smaller than those we identified in previous research for 1990 to 2006. For example, the average gap in terms of private credit to GDP was 12 percentage points for 1990-2006. In Figure 1, the average gap is 8. This provides one indication that Africa has witnessed improvements in financial development in recent years. ${ }^{4}$ A particular case is Kenya, which was below the predicted or the benchmark

\footnotetext{
${ }^{4}$ At the same time we note that 2007-2011 encapsulates the global financial crisis which affected other regions more than Sub-Saharan Africa (see, e.g. Devarajan and Fengler, 2013). This could have helped to narrow the gaps for African countries, and it might have weakened the relationships between financial development and its determinants in our regressions. Indeed the R-squared for the sample of non-African developing countries in
} 
development, is now right on the line. The more recent innovations in financial services and the emergence of Equity Bank seem to have contributed to Kenya's financial development path mirroring the other low and middle income countries outside Africa.

In terms of financial inclusion, the evidence is more mixed. The top panel of figure 2 shows that eighteen of thirty five countries have percentages of adults with a bank account above their predicted values. However, it appears that access to loans remains a very important obstacle to financial inclusion. The bottom panel of figure 2 shows that only three of thirty five countries have a percentage of adults with a loan from a financial institution above their predicted values. Those countries are Comoros, Swaziland and Mauritius.

Overall, the gap between predicted and observed African financial development is stark. The levels of liquid liabilities to GDP for African countries are about 78 percent the level predicted by statistical relationships that hold elsewhere in the developing world. Private credit ratios are even a bit lower. The percentage of adults with a loan from a formal financial institution is less than half of the predicted levels for African countries, though the share of adults with a bank account is near predicted levels.

To provide additional context for interpreting these gaps, the next sections look at whether the factors in our base models relate to African financial development differently than to financial development in the rest of the world.

\section{Are the Determinants of African Financial Development and Financial Inclusion Different?}

So far we have defined under-development in African financial sectors in terms of the determinants of financial development and financial inclusion in other parts of the developing world. However, the course of African financial sector development and financial inclusion might depend on a different set of factors than those that have been important elsewhere. While we are reluctant to accept that African financial sectors have a distinct model of development, it seems plausible that some factors may be somewhat more or less important in the African context. To see whether this is indeed the case, as a first

Table 5 are .12 to .40. However, for 1990-2006, R-squared statistics were similar, ranging from 0.14 to 0.43 (see Allen et al, forthcoming, Table 3). 
step, we estimate Equation (1) for the sample of African countries. Note that this method essentially accepts that the level of financial development and financial inclusion in Africa is lower than that in the rest of the developing world, and then tries to explain variation around the African mean based on the explanatory variables in our base models. Still, the results are instructive.

Tables 7 and 8 report the determinants of financial development and financial inclusion in Sub-Saharan African countries. Several coefficients are significant at standard confidence levels and all of these have the expected sign. Perhaps the most important difference between Africa and the rest of the developing world is that population density is much more strongly linked to both financial development and financial inclusion than it was elsewhere in the world. Moreover, our proxy for natural resources is strongly negatively linked to financial development and financial inclusion. GDP per capita and the KKM index are positively linked to financial development and financial inclusion for the African sample. In all, the determinants are more tightly linked to financial development and inclusion for African countries than for non-African countries. In part, this could be because the global financial crisis disrupted relationships between variables that held from 1990 to 2006 for non-African countries. Because Africa was less affected by the crisis, these relationships were less perturbed. In fact, the relationships are stronger within the African sample for 2007-2011 than they were for 1990-2006. Still, the importance of population density in explaining African financial development and inclusion stands out for 2007-2011 as it did for 19902006.

\section{The Impact of Mobile Banking on Financial Development and Inclusion in Africa}

Having established population density as a key factor for financial development and financial inclusion in Africa we explore whether innovations and financial services, such as mobile banking, have helped to overcome the financial gaps in Africa. As noted, the development of mobile banking in Africa started in Kenya with M-Pesa, which is a mobile phone-based service that greatly facilitates money transfers and remittances by the poor. It has been used primarily to transfer money between individuals rather than as a vehicle for saving. 
According to the World Bank Global Financial Inclusion (Global Findex) Dataset, by 2011 $67 \%$ and $60 \%$ of the adult population in Kenya used mobile telephones to receive and send money, respectively. Mobile banking spread quickly in Kenya thanks, in part, to the fact that the operator of M-PESA, Safaricom, controls two-thirds of the telecoms market in Kenya. However, as shown in Table 9, mobile banking has also taken off in other African countries such as Angola, Republic of Congo, Nigeria, Somalia, Sudan and Uganda.

Table 10 explores whether mobile banking has deeper penetration in Africa than elsewhere. To do so, we estimate a model similar to the one presented in Equation (1). We use three different dependent variables: the percentage of adults using a mobile telephone to (a) send money, (b) receive money, and (c) to pay bills. In addition, we augment the model with dummy variables for each region: East Asia and Pacific, Europe and Central Asia, Middle East and North Africa, South Asia, and Sub-Saharan Africa. The results suggest that the penetration of mobile telephones to receive and send money has been deeper in Sub-Saharan Africa than in the rest of the developing world. This result is robust even after controlling for our full set of country-variables. However, the penetration of mobile telephones to pay bills has not been stronger in Africa than in the rest of the developing world.

In all, the regression results in this section are consistent with the notion that mobile banking has advanced more rapidly in Africa than in other parts of the developing world (though not in terms of bill payment). Time will tell whether the initial inroads in terms of sending and receiving money via mobile phones will lead to deeper forms of financial inclusion (i.e., including savings accounts, loans, and other financial services such as insurance).

\section{Conclusions}

The available evidence provides a convincing linkage between financial development and economic development. Yet the level of financial development and financial inclusion remain very low in Africa based on standard indicators of banking development. Benchmarking based on the correlates of financial development and financial inclusion in other developing countries reveals a substantial gap between predicted and actual levels of African financial development and inclusion. 
Population density appears to be more important in Africa than elsewhere. Presumably, bank branch penetration figures remain low in Africa because of difficulties in achieving minimum viable scale in sparsely populated, low-income areas. Therefore, technological advances, such as mobile banking, that enable users of financial services to be located far away from their financial institutions, have provided a promising way to facilitate African financial development and financial inclusion outside major cities, a topic that has been studied in the context of Kenya, where the mobile payments services of M-PESA are now widely used (Mbiti and Weill, 2010; Jack and Suri, 2010).

At the same time, mobile banking has so far proven a success only within the context of sending and receiving money. While that could change, it seems likely that greater financial inclusion in terms of savings products, credit, and other financial services will require new approaches on the part of financial services providers. The experience of Equity Bank in Kenya provides one such example, and Equity Bank's more recent experience with agent banking, which employs small retailers as agents that can collect deposits, issue withdrawals, and process loan payments, provides another example. In addition, though we did not examine it in this paper, microfinance institutions have substantially increased their outreach in Africa over the past decade (Jarotschkin, 2013). In short, substantial gains in African financial inclusion and development are likely to require an array of new services, delivery channels, and providers, though there are signs that that process is already taking hold. 


\section{Appendix \\ Table A.1 \\ Variables Description}

\begin{tabular}{|c|c|c|}
\hline Variable & Description and unit & Source \\
\hline Liquid liabilities/GDP & Ratio of liquid liabilities to GDP & Financial Structure Dataset (Beck and Demirgüç-Kunt, 2009) \\
\hline Private credit/GDP & Private credit by deposit money banks to GDP & Financial Structure Dataset (Beck and Demirgüç-Kunt, 2009) \\
\hline Account at a formal financial institution & Account at a formal financial institution in the past year ( $\%$ of people older than 15 year old) & Global Findex Database (Demirguc-Kunt and Klapper, 2012) \\
\hline Loan from a financial institution & Loan from a financial institution in the past year ( $\%$ of people older than 15 year old) & Global Findex Database (Demirguc-Kunt and Klapper, 2012) \\
\hline Mobile phone used to pay bills & Mobile phone used to pay bills ( $\%$ of people older than 15 year old) & Global Findex Database (Demirguc-Kunt and Klapper, 2012) \\
\hline Mobile phone used to receive money & Mobile phone used to receive money ( $\%$ of people older than 15 year old) & Global Findex Database (Demirguc-Kunt and Klapper, 2012) \\
\hline Mobile phone used to send money & Mobile phone used to send money ( $\%$ of people older than 15 year old) & Global Findex Database (Demirguc-Kunt and Klapper, 2012) \\
\hline Population & Total population / 1,000,000 & World Development Indicators, World Bank \\
\hline Population Density & People per square $\mathrm{km}$ of land area $/ 1,000$ & World Development Indicators, World Bank \\
\hline Natural Resources & Net exports in resource intensive industries as described in the text. & Lederman and Maloney (2008) \\
\hline Offshore Center & Dummy variable that takes the value 1 if the country is a Offshore Center and 0 otherwise. & $\operatorname{IMF}(2007)$ \\
\hline GDP per capita & GDP per capita (constant 2000 US\$) & World Development Indicators, World Bank \\
\hline Growth GDP Per Capita & GDP per capita growth (annual \%) & World Development Indicators, World Bank \\
\hline Inflation & Inflation, consumer prices (annual \%) & World Development Indicators, World Bank \\
\hline KKM Index & Measure of broad institutional development & Kaufmann, Kraay, and Maztruzzi (2007) \\
\hline Manufacturing/GDP & Manufacturing ( $\%$ of GDP) & World Development Indicators, World Bank \\
\hline Secondary/Primary Enrollment & Secondary school enrollment over primary school enrollment & World Development Indicators, World Bank \\
\hline
\end{tabular}




\section{References}

Aker, Jenny C., Rachid Boumnijel, Amanda McClelland, and Niall Tierney, 2011. "Zap it to Me: The Short-term Impacts of a Mobile Cash Transfer Program." Center for Global Development working paper 268.

Aker, Jenny C. and Isaac M. Mbiti. 2010. "Mobile Phones and Economic Development in Africa." Journal of Economic Perspectives 24(3): 207-232.

Allen, Franklin, Elena Carletti, Robert Cull, Jun Qian, Lemma Senbet, and Patricio Valenzuela. Forthcoming. "Resolving the African Financial Development Gap: Cross-country Comparisons and a Within-country Study of Kenya," In NBER Volume on African Economic Successes, S. Edwards, S. Johnson, D. Weil. eds. Chicago: University of Chicago Press.

Allen, Franklin, Elena Carletti, Robert Cull, Jun Qian, Lemma Senbet and Patricio Valenzuela, 2012, "Improving Access to Banking: Evidence from Kenya," Wharton Financial Institutions Center Working Paper 12-07, University of Pennsylvania. Paper presented at the 2012 Summer Research Conference on "Recent Advances in Corporate Finance," at the Centre for Analytical Finance, Indian School of Business in Hyderabad.

Beck, Thortsen and Asli Demirgüç-Kunt, 2009, "Financial Institutions and Markets Across Countries and over Time: Data and Analysis," World Bank Policy Research Working Paper No. 4943.

Beck, Thorsten, Asli Demirgüç-Kunt, and Ross Levine, 2000, "A New Database on the Structure and Development of the Financial Sector," World Bank Economic Review 14, 597-605.

Beck, Thorsten, Asli Demirgüç-Kunt, and Ross Levine, 2007, "Finance, Inequality, and the Poor," Journal of Economic Growth 12, 27-49.

Beck, Thorsten, Erik Feyen, Alain Ize, and Florencia Moizeszowicz, 2008, "Benchmarking Financial Development,” World Bank Policy Research Working Paper 4638.

Brune, Lasse, Xavier Giné, Jessica Goldberg, and Dean Yang. 2011. "Commitments to Save: A Field Experiment in Rural Malawi." World Bank, policy research working paper 5748 .

Clarke, George R.G., L. Colin Xu, and Heng-Fu Zou, 2006, "Finance and Income Inequality: What Do the Data Tell Us?," Southern Economic Journal 72, 578-596.

Cull, Robert and Laurie Effron, 2008, "World Bank Lending and Financial Sector Development," World Bank Economic Review 22, 315-343. 
Cull Robert, Lemma W. Senbet and Marco Sorge, 2005, "Deposit Insurance and Financial Development," Journal of Money, Credit, and Banking 37, 43-82.

Devarajan, Shantayanan, and Wolfgang Fengler, 2013. “Africa's Economic Boom.” Foreign Affairs, 92(3): 68-81.

Dupas, Pascaline, and Jonathan Robinson, 2011. "Savings Constraints and Microenterprise Development: Evidence from a Field Experiment in Kenya." NBER working paper 14693.

Easterly, William and Ross Levine, 1997, “Africa's Growth Tragedy: Policies and Ethnic Divisions," Quarterly Journal of Economics 112, 1203-1250.

Honohan, Patrick and Thorsten Beck, eds., 2007, Making Finance Work for Africa, World Bank.

Jack, William, and Tavneet Suri, 2010, “The Economics of M-PESA,” MIT Sloan Working Paper.

Jarotschkin, Alexandra, 2013. "Microfinance in Africa." Chapter 1 in Thorsten Beack and Samuel Munzele Maimbo, Eds., Financial sector Development in Africa: Opportunities and Challenges, Washington, DC: The World Bank.

Kaufmann, Daniel, Aart Kraay, and Massimo Mastruzzi, 2007, "Governance Matters VI: Governance Indicators of 1996-2006," World Bank Policy Research Working Paper 4280 .

Lederman, Daniel, and William F. Maloney., 2008, "In Search of the Missing Resource Curse," Economía 9, 1-58.

Levine, Ross. 2005. "Finance and Growth: Theory and Evidence." In Philippe Aghion and Steven Durlauf (eds.), Handbook of Economic Growth. Amsterdam: Elsevier Science.

Levine, Ross, Norman Loayza, and Thorsten Beck, 2000, "Financial Intermediation and Growth: Causality and Causes," Journal of Monetary Economics 46, 31-77.

Levine, Ross and David Renelt. 1992. "A Sensitivity Analysis of Cross-Country Growth Regressions." American Economic Review 82, 942-63.

Loayza Norman and Roman Ranciere, 2006, "Financial Development, Financial Fragility, and Growth," Journal of Money, Credit, and Banking 38, 1051-1076.

Mbiti, Isaac, and David Weil, 2011, "Mobile Banking: The Impact of M-Pesa in Kenya," NBER Working Paper 17129.

Nissanke, Machiko and and Ernest Aryeetey 1998. Financial Integration and Development in SubSaharan Africa, ODI and Routledge, London and New York. 
Rajan, Raghuram G., and Luigi Zingales, 1998, "Financial Dependence and Growth," American Economic Review 88, 559-86.

Sachs, Jeffrey D. and Andrew Warner, 1995, "Natural Resource Abundance and Economic Growth,” National Bureau of Economic Research Working Paper 5398.

Sachs, Jeffrey D. and Andrew Warner, 2001, “The Curse of Natural Resources," European Economic Review 45, 827-838.

Senbet, Lemma and Isaac Otchere, 2008, "Financial Sector Reforms in Africa: Perspectives on Issues and Policies," World Bank Volume - Annual Bank Conference on Development Economics, eds. Francois Bourgignon and Boris Pleskovic: 81-119. 
Table 1

Financial Development by Regions

This table reports the evolution of liquid liabilities over GDP and private credit over GDP by regions. The period runs from 2000 to 2011 . Only middle and low income countries are considered. Regions correspond to the World Bank classification. The data source is the World Bank Database on Financial Development and Structure (Beck and Demirgüç-Kunt, 2009).

\begin{tabular}{|c|c|c|c|c|c|c|c|c|c|c|c|c|}
\hline Region & 2000 & 2001 & 2002 & 2003 & 2004 & 2005 & 2006 & 2007 & 2008 & 2009 & 2010 & 2011 \\
\hline & \multicolumn{12}{|c|}{ Liquid Liabilities/GDP } \\
\hline East Asia and Pacific & 55 & 57 & 58 & 56 & 57 & 60 & 60 & 62 & 63 & 69 & 71 & 74 \\
\hline Europe and Central Asia & 20 & 22 & 24 & 24 & 26 & 29 & 32 & 36 & 39 & 45 & 45 & 45 \\
\hline Latin America and the Caribbean & 43 & 45 & 46 & 46 & 46 & 46 & 46 & 47 & 48 & 52 & 53 & 54 \\
\hline Middle East and North Africa & 57 & 60 & 58 & 60 & 60 & 59 & 63 & 64 & 61 & 79 & 84 & 96 \\
\hline South Asia & 37 & 39 & 41 & 43 & 50 & 50 & 50 & 47 & 50 & 54 & 56 & 58 \\
\hline \multirow[t]{2}{*}{ Sub-Saharan Africa } & 26 & 26 & 27 & 28 & 27 & 27 & 29 & 29 & 30 & 33 & 35 & 37 \\
\hline & \multicolumn{12}{|c|}{ Private Credit Extended by Deposit Money Banks/GDP } \\
\hline East Asia and Pacific & 40 & 40 & 39 & 38 & 39 & 42 & 42 & 44 & 47 & 51 & 52 & 55 \\
\hline Europe and Central Asia & 11 & 12 & 13 & 14 & 17 & 20 & 25 & 32 & 42 & 42 & 40 & 40 \\
\hline Latin America and the Caribbean & 36 & 36 & 36 & 34 & 32 & 32 & 33 & 35 & 38 & 39 & 40 & 41 \\
\hline Middle East and North Africa & 32 & 33 & 29 & 29 & 28 & 29 & 32 & 33 & 31 & 35 & 37 & 47 \\
\hline South Asia & 21 & 22 & 22 & 22 & 25 & 29 & 32 & 32 & 36 & 38 & 39 & 40 \\
\hline Sub-Saharan Africa & 14 & 13 & 14 & 15 & 15 & 15 & 16 & 17 & 18 & 20 & 21 & 22 \\
\hline
\end{tabular}


Table 2

\section{Financial Inclusion by Regions}

This table reports the percentage of adult people (older than 15 years old) having an account at a formal financial institution and a loan from a financial institution by regions. The data correspond to the year 2011. Only middle and low income countries are considered. Regions correspond to the World Bank classification. The data source is the Global Financial Inclusion (Global Findex) Database.

\begin{tabular}{lcc}
\hline Region & $\begin{array}{c}\text { Account at a formal financial } \\
\text { institution }(\% \text { age } \mathbf{~ 1 5 + )}\end{array}$ & $\begin{array}{c}\text { Loan from a financial institution } \\
\text { in the past year }(\% \text { age } \mathbf{~ 1 5 + )}\end{array}$ \\
\hline East Asia and Pacific & 54.9 & 8.6 \\
Europe and Central Asia & 44.9 & 7.7 \\
Latin America and Caribbean & 39.3 & 7.9 \\
Middle East and North Africa & 17.7 & 5.1 \\
South Asia & 33.0 & 8.7 \\
Sub-Saharan Africa & 24.0 & 4.8 \\
\hline \hline
\end{tabular}


Table 3

Mobile Phone Use for Financial Transactions by Regions, 2011

This table reports the percentage of adult people (older than 15 years old) that use mobile telephones to send money, receive money and pay bills. The data correspond to the year 2011. Only middle and low income countries are considered. All countries with available data in these variables are considered in this table. Regions correspond to the World Bank classification. The data source is the Global Financial Inclusion (Global Findex) Database.

\begin{tabular}{lccc}
\hline Region & $\begin{array}{c}\text { Mobile phone used to } \\
\text { send money }\end{array}$ (\% age 15+) & $\begin{array}{c}\text { Mobile phone used to } \\
\text { receive money } \\
(\% \text { age 15+) }\end{array}$ & $\begin{array}{c}\text { Mobile phone used to } \\
\text { paills }(\% \text { age 15+) }\end{array}$ \\
\hline East Asia and Pacific & 1.0 & 1.2 & 1.3 \\
Europe and Central Asia & 2.5 & 2.7 & 3.0 \\
Latin America and Caribbean & 0.8 & 1.9 & 1.8 \\
Middle East and North Africa & 1.3 & 2.4 & 1.0 \\
South Asia & 0.8 & 1.9 & 2.1 \\
Sub-Saharan Africa & 11.2 & 14.6 & 3.0 \\
\hline \hline
\end{tabular}


Table 4

Summary Statistics

This table reports the mean and standard deviation of all the variables used in the regressions in this study.

\begin{tabular}{|c|c|c|c|c|}
\hline & \multicolumn{2}{|c|}{$\begin{array}{l}\text { Middle and Low Income Countries } \\
\text { (Sub-Saharan excluded) }\end{array}$} & \multicolumn{2}{|c|}{ Sub-Saharan Countries } \\
\hline & Mean & Std. Dev. & Mean & Std. Dev. \\
\hline \multicolumn{5}{|l|}{ Dependent variables } \\
\hline Liquid liabilities/GDP & $55.4 \%$ & $32.7 \%$ & $31.8 \%$ & $16.8 \%$ \\
\hline Private credit/GDP & $40.0 \%$ & $24.7 \%$ & $19.4 \%$ & $16.9 \%$ \\
\hline Account at a formal financial institution & $35.2 \%$ & $21.5 \%$ & $21.0 \%$ & $16.3 \%$ \\
\hline Loan from a financial institution & $10.1 \%$ & $6.1 \%$ & $5.2 \%$ & $3.2 \%$ \\
\hline Mobile phone used to send money & $2.3 \%$ & $4.1 \%$ & $8.8 \%$ & $13.2 \%$ \\
\hline Mobile phone used to receive money & $3.5 \%$ & $6.1 \%$ & $11.9 \%$ & $15.3 \%$ \\
\hline Mobile phone used to pay bills & $2.5 \%$ & $4.4 \%$ & $3.3 \%$ & $5.1 \%$ \\
\hline \multicolumn{5}{|l|}{ Explanatory variables } \\
\hline Population & 50.6 & 184.1 & 18.3 & 27.1 \\
\hline Population density & 0.131 & 0.179 & 0.090 & 0.123 \\
\hline Natural resources & 0.063 & 0.385 & 0.112 & 0.650 \\
\hline Offshore center & $6.5 \%$ & $24.70 \%$ & $0.00 \%$ & $0.00 \%$ \\
\hline GDP per capita & 2,824 & 2,444 & 865 & 1221 \\
\hline GDP & 0.102 & 0.344 & 0.012 & 0.030 \\
\hline Growth GDP per capita & $3.1 \%$ & $2.8 \%$ & $2.3 \%$ & $2.2 \%$ \\
\hline Inflation & $7.2 \%$ & $4.2 \%$ & $8.1 \%$ & $5.0 \%$ \\
\hline KKM Index & -0.393 & 0.612 & -0.681 & 0.633 \\
\hline Manufacturing/GDP & $14.7 \%$ & $7.5 \%$ & $10.2 \%$ & $6.6 \%$ \\
\hline Secondary/Primary enrollment & 0.670 & 0.206 & 0.331 & 0.163 \\
\hline
\end{tabular}


Table 5

\section{Regressions on Financial Development for the sample of Middle and Low Income} non-Sub-Saharan countries

This table presents OLS regressions of liquid liabilities over GDP and private credit over GDP on the set of country-level variables listed below. This table reports the models for a sample of low and middle income nonSub-Saharan African countries. ***, **, and * indicate significance at the 1\%,5\% and 10\% levels, respectively.

\begin{tabular}{|c|c|c|c|c|}
\hline & \multicolumn{2}{|c|}{ Liquid Liabilities / GDP } & \multicolumn{2}{|c|}{ Private Credit / GDP } \\
\hline & $(1)$ & $(2)$ & $(3)$ & $(4)$ \\
\hline \multirow[t]{2}{*}{ Ln(Population) } & 0.0246 & 0.0338 & 0.0129 & 0.0252 \\
\hline & $(0.020)$ & $(0.025)$ & $(0.014)$ & $(0.016)$ \\
\hline \multirow[t]{2}{*}{ Ln(Population Density) } & 0.0443 & 0.0489 & $0.0375^{*}$ & 0.0220 \\
\hline & $(0.032)$ & $(0.036)$ & $(0.022)$ & $(0.023)$ \\
\hline \multirow[t]{2}{*}{ Natural Resources } & -0.1571 & -0.0902 & $-0.1569 * *$ & $-0.1352 *$ \\
\hline & $(0.103)$ & $(0.110)$ & $(0.072)$ & $(0.069)$ \\
\hline \multirow[t]{2}{*}{ Offshore Center } & $0.3515^{* *}$ & $0.3487 * *$ & $0.3152 * * *$ & $0.3423 * * *$ \\
\hline & $(0.150)$ & $(0.174)$ & $(0.104)$ & $(0.109)$ \\
\hline \multirow[t]{2}{*}{ Ln(GDP per capita) } & $0.0823^{*}$ & 0.0348 & $0.0993 * * *$ & -0.0158 \\
\hline & $(0.042)$ & $(0.062)$ & $(0.029)$ & $(0.038)$ \\
\hline \multirow[t]{2}{*}{ Growth GDP Per Capita } & & 2.4203 & & 0.2869 \\
\hline & & $(1.542)$ & & $(0.965)$ \\
\hline \multirow[t]{2}{*}{ Inflation } & & $-1.7581 *$ & & -0.1919 \\
\hline & & $(1.004)$ & & $(0.628)$ \\
\hline \multirow[t]{2}{*}{ KKM Index } & & 0.1118 & & $0.2420 * * *$ \\
\hline & & $(0.099)$ & & $(0.062)$ \\
\hline \multirow[t]{2}{*}{ Manufacturing/GDP } & & -0.3958 & & 0.3774 \\
\hline & & $(0.641)$ & & $(0.401)$ \\
\hline \multirow[t]{2}{*}{ Secondary/Primary Enrollment } & & 0.0297 & & 0.0952 \\
\hline & & $(0.242)$ & & $(0.151)$ \\
\hline \multirow[t]{2}{*}{ Constant } & $0.5530 * * *$ & $0.7054 * * *$ & $0.3985^{* * *}$ & $0.3659 * * *$ \\
\hline & $(0.116)$ & $(0.189)$ & $(0.081)$ & $(0.118)$ \\
\hline Observations & 77 & 72 & 77 & 72 \\
\hline Adjusted R-squared & 0.1246 & 0.1644 & 0.2582 & 0.4019 \\
\hline
\end{tabular}


Table 6

\section{Regressions on Financial Inclusion for the sample of Middle and Low Income non-} Sub-Saharan countries

This table presents OLS regressions of the percentage of adults with an account a formal institution, and the percentage of adults with a loan from a formal institution on the set of country-level variables listed below. This table reports the models for the sample of low and middle income non-Sub-Saharan African countries. $* * *, * *$, and $*$ indicate significance at the $1 \%, 5 \%$ and $10 \%$ levels, respectively.

\begin{tabular}{|c|c|c|c|c|}
\hline & \multicolumn{2}{|c|}{$\begin{array}{c}\text { Account at a formal financial } \\
\text { institution }\end{array}$} & \multicolumn{2}{|c|}{$\begin{array}{l}\text { Loan from a financial } \\
\text { institution }\end{array}$} \\
\hline & (1) & (2) & (3) & (4) \\
\hline \multirow[t]{2}{*}{ Ln(Population) } & 0.0125 & 0.0223 & -0.0021 & -0.0037 \\
\hline & $(0.018)$ & $(0.019)$ & $(0.006)$ & $(0.006)$ \\
\hline \multirow[t]{2}{*}{ Ln(Population Density) } & -0.0021 & -0.0045 & 0.0005 & 0.0003 \\
\hline & $(0.024)$ & $(0.026)$ & $(0.008)$ & $(0.008)$ \\
\hline \multirow[t]{2}{*}{ Natural Resources } & -0.0095 & -0.0018 & -0.0009 & 0.0009 \\
\hline & $(0.075)$ & $(0.077)$ & $(0.024)$ & $(0.025)$ \\
\hline \multirow[t]{2}{*}{ Offshore Center } & -0.0066 & 0.0060 & 0.0118 & -0.0083 \\
\hline & $(0.147)$ & $(0.148)$ & $(0.048)$ & $(0.047)$ \\
\hline \multirow[t]{2}{*}{ Ln(GDP per capita) } & $0.1142^{* * *}$ & 0.0415 & -0.0078 & -0.0083 \\
\hline & $(0.030)$ & $(0.040)$ & $(0.010)$ & $(0.013)$ \\
\hline \multirow[t]{2}{*}{ Growth GDP Per Capita } & & -0.1518 & & $0.9145^{* *}$ \\
\hline & & $(1.109)$ & & $(0.356)$ \\
\hline \multirow[t]{2}{*}{ Inflation } & & 0.4664 & & 0.2028 \\
\hline & & $(0.636)$ & & $(0.204)$ \\
\hline \multirow[t]{2}{*}{ KKM Index } & & $0.1319 *$ & & 0.0174 \\
\hline & & $(0.066)$ & & $(0.021)$ \\
\hline \multirow[t]{2}{*}{ Manufacturing/GDP } & & 0.0793 & & -0.0532 \\
\hline & & $(0.415)$ & & $(0.133)$ \\
\hline \multirow[t]{2}{*}{ Secondary/Primary Enrollment } & & 0.1996 & & -0.0332 \\
\hline & & $(0.174)$ & & $(0.056)$ \\
\hline \multirow[t]{2}{*}{ Constant } & $0.2386^{* *}$ & 0.1265 & $0.1128 * * *$ & $0.1111 * *$ \\
\hline & $(0.097)$ & $(0.146)$ & $(0.031)$ & $(0.047)$ \\
\hline Observations & 64 & 61 & 64 & 61 \\
\hline Adjusted R-squared & 0.1571 & 0.1971 & -0.0697 & -0.0128 \\
\hline
\end{tabular}


Table 7

Regressions on Financial Development for the sample of Sub-Saharan African countries

This table presents OLS regressions of percentage of people with an account at a formal financial institution on the set of country-level variables listed below. This table reports the models for the sample of Sub-Saharan African countries (including and excluding South Africa). ***, **, and * indicate significance at the $1 \%, 5 \%$ and $10 \%$ levels, respectively.

\begin{tabular}{|c|c|c|c|c|c|c|c|c|}
\hline & \multicolumn{4}{|c|}{ Liquid Liabilities / GDP } & \multicolumn{4}{|c|}{ Private Credit / GDP } \\
\hline & \multicolumn{2}{|c|}{ All } & \multicolumn{2}{|c|}{ Without South Africa } & \multicolumn{2}{|c|}{ All } & \multicolumn{2}{|c|}{ Without South Africa } \\
\hline & (1) & $(2)$ & $(3)$ & $(4)$ & $(5)$ & $(6)$ & $(7)$ & $(8)$ \\
\hline \multirow[t]{2}{*}{ Ln(Population) } & -0.0115 & -0.0102 & -0.0145 & -0.0135 & 0.0177 & 0.0237 & 0.0040 & 0.0083 \\
\hline & $(0.012)$ & $(0.013)$ & $(0.014)$ & $(0.014)$ & $(0.013)$ & $(0.014)$ & $(0.013)$ & $(0.015)$ \\
\hline \multirow[t]{2}{*}{ Ln(Population Density) } & $0.0481 * * *$ & $0.0458 * * *$ & $0.0476^{* * *}$ & $0.0458^{* * *}$ & $0.0344 * *$ & $0.0286^{*}$ & $0.0320^{* *}$ & $0.0286^{* *}$ \\
\hline & $(0.013)$ & $(0.012)$ & $(0.013)$ & $(0.013)$ & $(0.013)$ & $(0.014)$ & $(0.012)$ & $(0.013)$ \\
\hline \multirow[t]{2}{*}{ Natural Resources } & $-0.0892^{* * *}$ & $-0.0709 * * *$ & $-0.0879 * * *$ & $-0.0720 * * *$ & $-0.0853 * * *$ & $-0.0580^{*}$ & $-0.0795^{* * *}$ & $-0.0630 * *$ \\
\hline & $(0.025)$ & $(0.026)$ & $(0.025)$ & $(0.026)$ & $(0.026)$ & $(0.029)$ & $(0.024)$ & $(0.028)$ \\
\hline \multirow[t]{2}{*}{ Ln(GDP per capita) } & $0.1326^{* * *}$ & $0.0842 * *$ & $0.1270 * * *$ & $0.0845^{* *}$ & $0.1519^{* * *}$ & $0.0858^{* *}$ & $0.1264 * * *$ & $0.0869 * *$ \\
\hline & $(0.018)$ & $(0.031)$ & $(0.021)$ & $(0.031)$ & $(0.019)$ & $(0.035)$ & $(0.020)$ & $(0.033)$ \\
\hline \multirow[t]{2}{*}{ Growth GDP Per Capita } & & $1.4790^{*}$ & & $1.5291 *$ & & 0.8870 & & 1.1229 \\
\hline & & $(0.836)$ & & $(0.853)$ & & $(0.951)$ & & $(0.901)$ \\
\hline \multirow[t]{2}{*}{ Inflation } & & -0.3070 & & -0.2815 & & -0.4902 & & -0.3705 \\
\hline & & $(0.417)$ & & $(0.426)$ & & $(0.474)$ & & $(0.449)$ \\
\hline \multirow[t]{2}{*}{ KKM Index } & & $0.0790^{* *}$ & & $0.0774 * *$ & & $0.0727 *$ & & $0.0650^{*}$ \\
\hline & & $(0.032)$ & & $(0.033)$ & & $(0.037)$ & & $(0.035)$ \\
\hline \multirow[t]{2}{*}{ Manufacturing/GDP } & & -0.3115 & & -0.3263 & & 0.0318 & & -0.0378 \\
\hline & & $(0.242)$ & & $(0.247)$ & & $(0.275)$ & & $(0.261)$ \\
\hline \multirow[t]{2}{*}{ Secondary/Primary Enrollment } & & 0.1421 & & 0.1115 & & 0.2289 & & 0.0848 \\
\hline & & $(0.138)$ & & $(0.152)$ & & $(0.156)$ & & $(0.161)$ \\
\hline \multirow[t]{2}{*}{ Constant } & $0.5984 * * *$ & $0.5761 * * *$ & $0.5976^{* * *}$ & $0.5895^{* * *}$ & $0.3774 * * *$ & $0.2810^{* *}$ & $0.3737 * * *$ & $0.3440^{* * *}$ \\
\hline & $(0.050)$ & $(0.095)$ & $(0.050)$ & $(0.100)$ & $(0.052)$ & $(0.108)$ & $(0.048)$ & (0.106) \\
\hline Observations & 40 & 40 & 39 & 39 & 40 & 40 & 39 & 39 \\
\hline Adjusted R-squared & 0.6686 & 0.7292 & 0.6437 & 0.7071 & 0.6283 & 0.6505 & 0.5765 & 0.5850 \\
\hline
\end{tabular}


Table 8

Regressions on Financial Inclusion for the sample of Sub-Saharan African countries

This table presents OLS regressions of percentage of people with a loan from a formal financial institution on the set of country-level variables listed below. This table reports the models for the sample of Sub-Saharan African countries (including and excluding South Africa). ***, **, and * indicate significance at the $1 \%, 5 \%$ and $10 \%$ levels, respectively.

\begin{tabular}{|c|c|c|c|c|c|c|c|c|}
\hline & \multicolumn{4}{|c|}{ Account at a formal financial institution } & \multicolumn{4}{|c|}{ Loan from a financial institution } \\
\hline & \multicolumn{2}{|c|}{ All } & \multicolumn{2}{|c|}{ Without South Africa } & \multicolumn{2}{|c|}{ All } & \multicolumn{2}{|c|}{ Without South Africa } \\
\hline & $(1)$ & $(2)$ & (3) & $(4)$ & $(5)$ & $(6)$ & $(7)$ & $(8)$ \\
\hline $\operatorname{Ln}$ (Population) & $\begin{array}{l}0.0211 \\
(0.017)\end{array}$ & $\begin{array}{l}0.0077 \\
(0.016)\end{array}$ & $\begin{array}{l}0.0198 \\
(0.018)\end{array}$ & $\begin{array}{c}-0.0004 \\
(0.018)\end{array}$ & $\begin{array}{r}-0.0027 \\
(0.004)\end{array}$ & $\begin{array}{r}-0.0045 \\
(0.004)\end{array}$ & $\begin{array}{r}-0.0028 \\
(0.004)\end{array}$ & $\begin{array}{r}-0.0062 \\
(0.005)\end{array}$ \\
\hline Ln(Population Density) & $\begin{array}{c}0.0473^{* * *} \\
(0.015)\end{array}$ & $\begin{array}{c}0.0393 * * \\
(0.014)\end{array}$ & $\begin{array}{c}0.0472^{* * *} \\
(0.015)\end{array}$ & $\begin{array}{c}0.0389^{* *} \\
(0.014)\end{array}$ & $\begin{array}{c}0.0082^{* *} \\
(0.003)\end{array}$ & $\begin{array}{l}0.0059 \\
(0.004)\end{array}$ & $\begin{array}{c}0.0082^{* *} \\
(0.003)\end{array}$ & $\begin{array}{l}0.0059 \\
(0.004)\end{array}$ \\
\hline Natural Resources & $\begin{array}{r}-0.0488 \\
(0.030)\end{array}$ & $\begin{array}{r}-0.0432 \\
(0.030)\end{array}$ & $\begin{array}{r}-0.0482 \\
(0.030)\end{array}$ & $\begin{array}{r}-0.0446 \\
(0.030)\end{array}$ & $\begin{array}{c}-0.0152^{* *} \\
(0.007)\end{array}$ & $\begin{array}{c}-0.0146^{*} \\
(0.008)\end{array}$ & $\begin{array}{c}-0.0151^{* *} \\
(0.007)\end{array}$ & $\begin{array}{c}-0.0149 * \\
(0.008)\end{array}$ \\
\hline Ln(GDP per capita) & $\begin{array}{c}0.1375^{* * *} \\
(0.023)\end{array}$ & $\begin{array}{c}0.1208^{* * *} \\
(0.036)\end{array}$ & $\begin{array}{c}0.1352 * * * \\
(0.027)\end{array}$ & $\begin{array}{c}0.1179 * * * \\
(0.036)\end{array}$ & $\begin{array}{c}0.0187 * * * \\
(0.005)\end{array}$ & $\begin{array}{c}0.0192 * \\
(0.009)\end{array}$ & $\begin{array}{c}0.0184 * * * \\
(0.006)\end{array}$ & $\begin{array}{c}0.0185^{*} \\
(0.010)\end{array}$ \\
\hline Growth GDP Per Capita & & $\begin{array}{c}2.5315^{* *} \\
(0.993)\end{array}$ & & $\begin{array}{c}2.6830^{* *} \\
(1.008)\end{array}$ & & $\begin{array}{l}0.3587 \\
(0.259)\end{array}$ & & $\begin{array}{l}0.3914 \\
(0.265)\end{array}$ \\
\hline Inflation & & $\begin{array}{l}0.1562 \\
(0.502)\end{array}$ & & $\begin{array}{l}0.2114 \\
(0.507)\end{array}$ & & $\begin{array}{l}0.0647 \\
(0.131)\end{array}$ & & $\begin{array}{l}0.0767 \\
(0.133)\end{array}$ \\
\hline KKM Index & & $\begin{array}{l}0.0418 \\
(0.038)\end{array}$ & & $\begin{array}{l}0.0407 \\
(0.038)\end{array}$ & & $\begin{array}{l}0.0054 \\
(0.010)\end{array}$ & & $\begin{array}{l}0.0051 \\
(0.010)\end{array}$ \\
\hline Manufacturing/GDP & & $\begin{array}{r}-0.0137 \\
(0.290)\end{array}$ & & $\begin{array}{r}-0.0507 \\
(0.293)\end{array}$ & & $\begin{array}{l}0.0670 \\
(0.076)\end{array}$ & & $\begin{array}{l}0.0590 \\
(0.077)\end{array}$ \\
\hline Secondary/Primary Enrollment & & $\begin{array}{r}-0.0194 \\
(0.149)\end{array}$ & & $\begin{array}{r}-0.0754 \\
(0.161)\end{array}$ & & $\begin{array}{r}-0.0388 \\
(0.039)\end{array}$ & & $\begin{array}{c}-0.0509 \\
(0.042)\end{array}$ \\
\hline Constant & $\begin{array}{c}0.4174 * * * \\
(0.062)\end{array}$ & $\begin{array}{c}0.3643^{* * *} \\
(0.109)\end{array}$ & $\begin{array}{c}0.4176^{* * * *} \\
(0.063)\end{array}$ & $\begin{array}{c}0.3889 * * * \\
(0.113)\end{array}$ & $\begin{array}{c}0.1018^{* * *} \\
(0.014)\end{array}$ & $\begin{array}{c}0.0939 * * * \\
(0.029)\end{array}$ & $\begin{array}{c}0.1018^{* * *} \\
(0.014)\end{array}$ & $\begin{array}{c}0.0992^{* * *} \\
(0.030)\end{array}$ \\
\hline Observations & 36 & 35 & 35 & 34 & 36 & 35 & 35 & 34 \\
\hline Adjusted R-squared & 0.5420 & 0.6458 & 0.4795 & 0.6049 & 0.3755 & 0.3698 & 0.3496 & 0.3554 \\
\hline
\end{tabular}


Table 9

\section{Mobile Phone Use in Financial Transactions by Country}

This table reports the percentages of adult population (older than 15 years old) that use mobile phones to pay bills and receive and send money. The table only includes Sub-Saharan African countries.

\begin{tabular}{|c|c|c|c|}
\hline Country & $\begin{array}{l}\text { Mobile phone used to } \\
\text { pay bills }\end{array}$ & $\begin{array}{c}\text { Mobile phone used to } \\
\text { receive money } \\
(\% \text { age } 15+)\end{array}$ & $\begin{array}{l}\text { Mobile phone used to } \\
\text { send money }\end{array}$ \\
\hline Angola & 13.6 & 19.3 & 11.7 \\
\hline Benin & 0.2 & 0.4 & 0.2 \\
\hline Botswana & 2.2 & 8.0 & 5.1 \\
\hline Burkina Faso & 0.3 & 0.6 & 0.2 \\
\hline Burundi & 0.8 & 4.7 & 4.0 \\
\hline Cameroon & 0.6 & 8.8 & 3.3 \\
\hline Central African Repuk & 0.2 & 1.6 & 0.3 \\
\hline Chad & 2.8 & 15.5 & 5.7 \\
\hline Comoros & 0.3 & 3.5 & 0.5 \\
\hline Congo, Dem. Rep. & 0.1 & 2.0 & 1.5 \\
\hline Congo, Rep. & 1.6 & 32.0 & 20.1 \\
\hline Gabon & 4.9 & 46.6 & 41.1 \\
\hline Ghana & 0.9 & 1.5 & 1.0 \\
\hline Guinea & 1.1 & 5.7 & 3.5 \\
\hline Kenya & 13.4 & 66.7 & 60.5 \\
\hline Lesotho & 4.6 & 6.7 & 5.7 \\
\hline Liberia & 5.2 & 16.6 & 7.3 \\
\hline Madagascar & 0.0 & 0.7 & 0.8 \\
\hline Malawi & 0.8 & 0.7 & 0.5 \\
\hline Mali & 0.3 & 1.0 & 0.3 \\
\hline Mauritania & 7.5 & 16.0 & 7.1 \\
\hline Mauritius & 1.8 & 7.3 & 6.8 \\
\hline Mozambique & 1.3 & 1.4 & 1.0 \\
\hline Niger & 0.4 & 2.6 & 0.9 \\
\hline Nigeria & 1.4 & 11.2 & 9.9 \\
\hline Rwanda & 1.1 & 2.9 & 2.0 \\
\hline Senegal & 0.2 & 0.9 & 0.5 \\
\hline Sierra Leone & 0.7 & 1.9 & 1.4 \\
\hline Somalia & 26.2 & 32.2 & 31.7 \\
\hline South Africa & 4.4 & 9.4 & 5.4 \\
\hline Sudan & 4.0 & 44.7 & 30.5 \\
\hline Swaziland & 4.7 & 16.4 & 16.2 \\
\hline Tanzania & 5.5 & 19.6 & 14.0 \\
\hline Togo & 0.4 & 1.1 & 0.2 \\
\hline Uganda & 3.3 & 25.2 & 20.0 \\
\hline Zambia & 2.4 & 3.5 & 3.0 \\
\hline Zimbabwe & 2.6 & 1.8 & 1.5 \\
\hline
\end{tabular}




\section{Table 10}

\section{Regressions on Mobile Phone Penetration}

This table presents OLS regressions of percentage of people using mobile phone to make financial transactions on the set of country-level variables listed below. This table reports the models for all low and middle income countries. ${ }^{* *}, * *$, and $*$ indicate significance at the $1 \%, 5 \%$ and $10 \%$ levels, respectively.

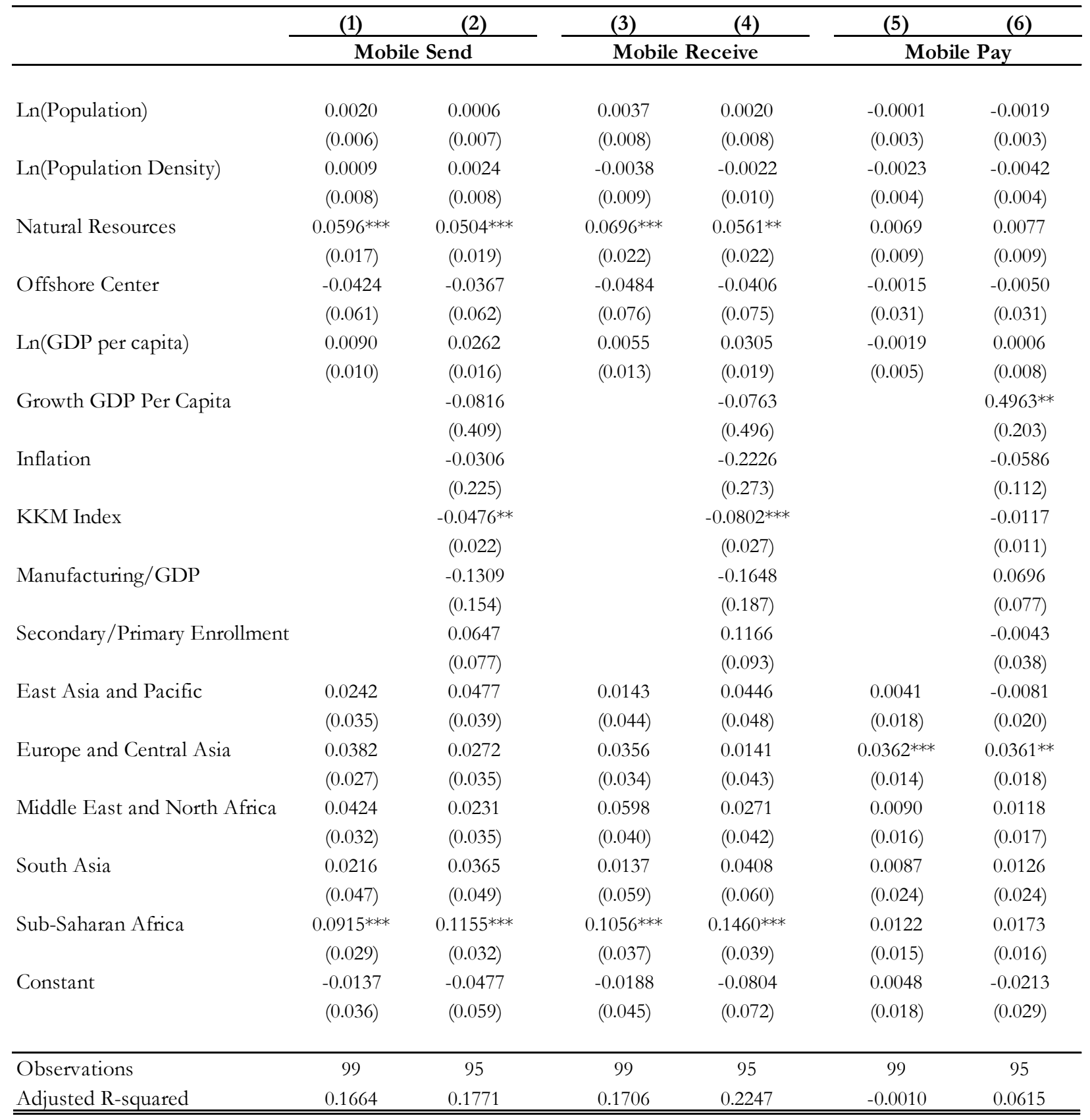



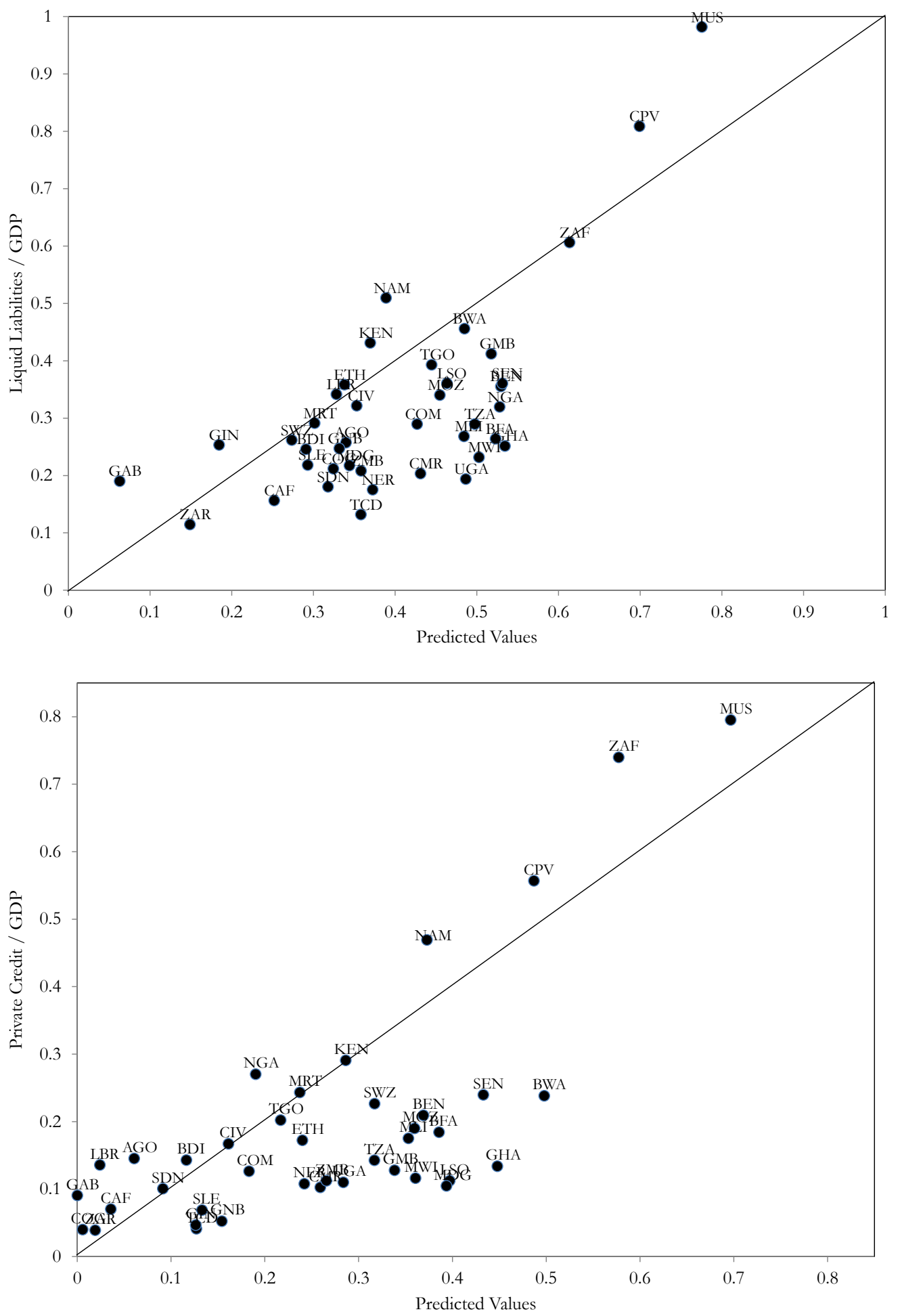

Figure 1. Liquid liabilities/GDP and Private Credit/GDP in African countries, actual vs. predicted values (Notes: The negative predicted value for Gabon was replaced by zero). 

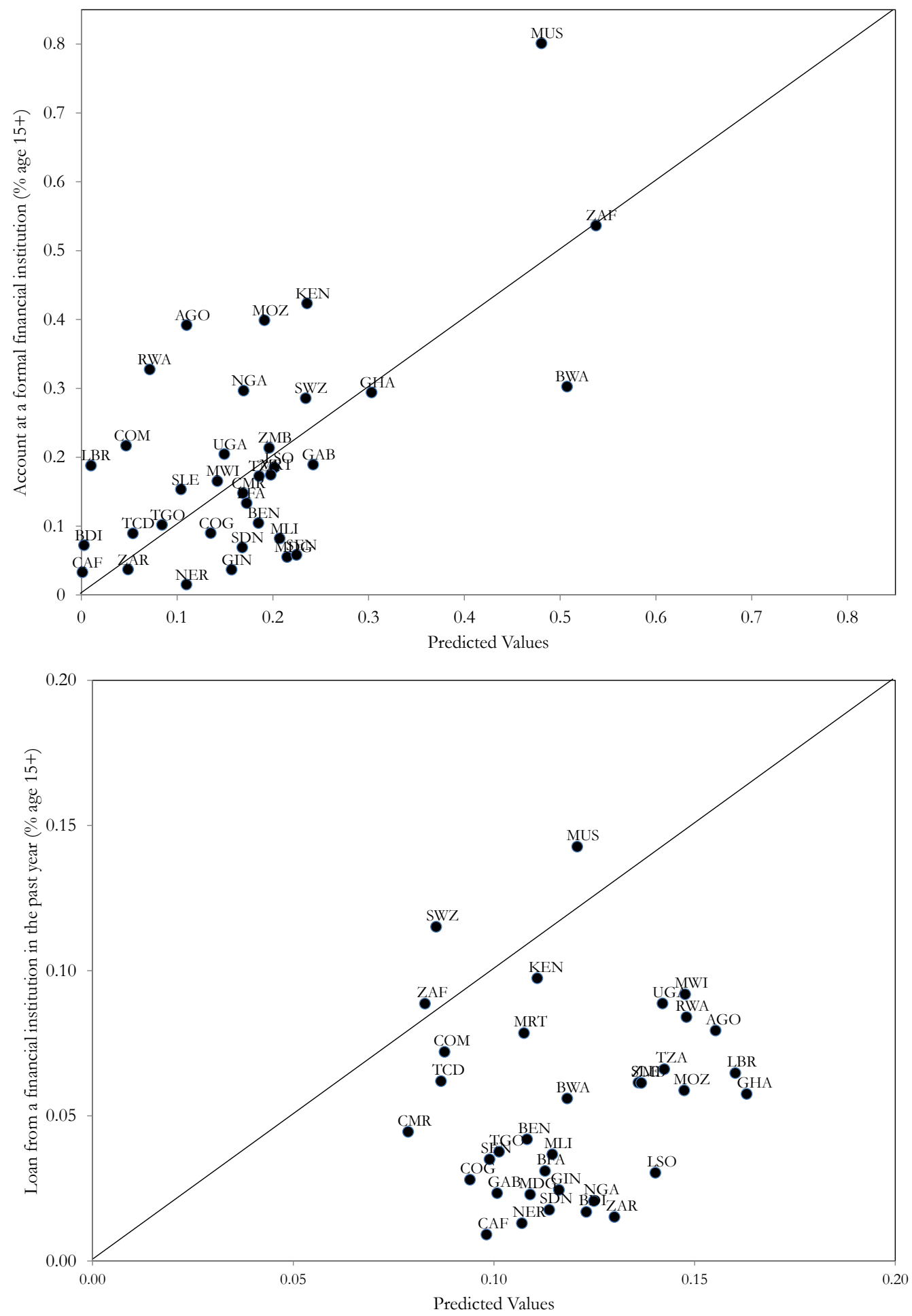

Figure 2. Account at a formal financial institution and loan from a financial institution, actual vs. predicted values. (Notes: Negative predicted values were replaced by zero). 


\section{Centro de Economía Aplicada \\ Departamento de Ingeniería Industrial \\ Universidad de Chile}

\section{3}

305. The African Financial Development and Financial Inclusion Gaps

Franklin Allen, Elena Carletti, Robert Cull, Jun “Qj” Qian, Lemma Senbet y Patricio Valenzuela

304. Revealing Bargaining Power through Actual Wholesale Prices

Carlos Noton y Andrés Elberg

303. Structural Estimation of Price Adjustment Costs in the European Car Market

Carlos Noton

302. Remedies for Sick Insurance

Daniel McFadden, Carlos Noton y Pau Olivella

301. Minimum Coverage Regulation in Insurance Markets

Daniel McFadden, Carlos Noton y Pau Olivella

300. Rollover risk and corporate bond spreads

Patricio Valenzuela

299. Sovereign Ceilings "Lite"? The Impact of Sovereign Ratings on Corporate Ratings

Eduardo Borensztein, Kevin Cowan y Patricio Valenzuela

298. Improving Access to Banking: Evidence from Kenya

F. Allen, E. Carletti, R. Cull, J.“Qj” Qian, L. Senbet y P. Valenzuela

297. Financial Openness, Market Structure and Private Credit: An Empirical Investigation

Ronald Fischer y Patricio Valenzuela

296. Banking Competition and Economic Stability

Ronald Fischer, Nicolás Inostroza y Felipe J. Ramírez

295. Trust in Cohesive Communities

Felipe Balmaceda y Juan F. Escobar

294. A Spatial Model of Voting with Endogenous Proposals: Theory and Evidence from Chilean Senate

Matteo Triossi, Patricio Valdivieso y Benjamín Villena-Roldán

\section{2}

293. Participation in Organizations, Trust, and Social Capital Formation: Evidence from Chile

Patricio Valdivieso - Benjamín Villena-Roldán

292. Neutral Mergers Between Bilateral Markets

Antonio Romero-Medina y Matteo Triossi 
291. On the Optimality of One-size-fits-all Contracts: The Limited Liability Case

Felipe Balmaceda

290. Self Governance in Social Networks of Information Transmission

Felipe Balmaceda y Juan F. Escobar

289. Efficiency in Games with Markovian Private Information

Juan F. Escobar y Juuso Toikka

288. EPL and Capital-Labor Ratios

Alexandre Janiaka y Etienne Wasmer

287. Minimum Wages Strike Back: The Effects on Capital and Labor Demands in a Large-Firm Framework

Sofía Bauducco y Alexandre Janiak

\section{1}

286. Comments on Donahue and Zeckhauser: Collaborative Governance Ronald Fischer

285. Casual Effects of Maternal Time-Investment on children's Cognitive Outcomes Benjamín Villena-Rodán y Cecilia Ríos-Aguilar

284. Towards a Quantitative Theory of Automatic Stabilizers: The Role of Demographics Alexandre Janiak y Paulo Santos Monteiro

283. Investment and Environmental Regulation: Evidence on the Role of Cash Flow Evangelina Dardati y Julio Riutort

282. Teachers' Salaries in Latin America. How Much are They (under or over) Paid? Alejandra Mizala y Hugo Nopo

281. Acyclicity and Singleton Cores in Matching Markets Antonio Romero-Medina y Matteo Triossi

280. Games with Capacity Manipulation: Incentives and Nash Equilibria Antonio Romero-Medina y Matteo Triossi

279. Job Design and Incentives Felipe Balmaceda

278. Unemployment, Participation and Worker Flows Over the Life Cycle Sekyu Choi - Alexandre Janiak -Benjamín Villena-Roldán

277. Public-Private Partnerships and Infrastructure Provision in the United States (Publicado como "Public-Private-Partnerships to Revamp U.S. Infrastructure". Hamilton Policy Brief, Brookings Institution 2011)

Eduardo Engel, Ronald Fischer y Alexander Galetovic 


\section{0}

276. The economics of infrastructure finance: Public-private partnerships versus public provision (Publicado en European Investment Bank Papers, 15(1), pp 40-69.2010)

Eduardo Engel, Ronald Fischer y Alexander Galetovic

275. The Cost of Moral Hazard and Limited Liability in the Principal-Agent Problem

F. Balmaceda, S.R. Balseiro, J.R. Correa y N.E. Stier-Moses

274. Structural Unemployment and the Regulation of Product Market

Alexandre Janiak

273. Non-revelation Mechanisms in Many-to-One Markets

Antonio Romero-Medina y Matteo Triossi

272. Labor force heterogeneity: implications for the relation between aggregate volatility and government size

Alexandre Janiak y Paulo Santos Monteiro

271. Aggregate Implications of Employer Search and Recruiting Selection

Benjamín Villena Roldán

270. Wage dispersion and Recruiting Selection

Benjamín Villena Roldán

269. Parental decisions in a choice based school system: Analyzing the transition between primary and secondary school

Mattia Makovec, Alejandra Mizala y Andrés Barrera

268. Public-Private Wage Gap In Latin America (1999-2007): A Matching Approach

(Por aparecer en Labour Economics, (doi:10.1016/j.labeco.2011.08.004))

Alejandra Mizala, Pilar Romaguera y Sebastián Gallegos

267. Costly information acquisition. Better to toss a coin?

Matteo Triossi

266. Firm-Provided Training and Labor Market Institutions

Felipe Balmaceda

\section{9}

265. Soft budgets and Renegotiations in Public-Private Partnerships

Eduardo Engel, Ronald Fischer y Alexander Galetovic

264. Information Asymmetries and an Endogenous Productivity Reversion Mechanism Nicolás Figueroa y Oksana Leukhina

263. The Effectiveness of Private Voucher Education: Evidence from Structural School Switches (Publicado en Educational Evaluation and Policy Analysis Vol. 33 No 2 2011. pp. 119-137)

Bernardo Lara, Alejandra Mizala y Andrea Repetto 
262. Renegociación de concesiones en Chile

(Publicado como "Renegociación de Concesiones en Chile". Estudios Públicos, 113, Verano, 151-205. 2009)

Eduardo Engel, Ronald Fischer, Alexander Galetovic y Manuel Hermosilla

261. Inflation and welfare in long-run equilibrium with firm dynamics

Alexandre Janiak y Paulo Santos Monteiro

260. Conflict Resolution in the Electricity Sector - The Experts Panel of Chile

R. Fischer, R. Palma-Behnke y J. Guevara-Cedeño

259. Economic Performance, creditor protection and labor inflexibility

(Publicado como "Economic Performance, creditor protection and labor inflexibility". Oxford Economic Papers, 62(3),553-577. 2010)

Felipe Balmaceda y Ronald Fischer

258. Effective Schools for Low Income Children: a Study of Chile's Sociedad de Instrucción Primaria (Publicado en Applied Economic Letters 19, 2012, pp. 445-451)

Francisco Henríquez, Alejandra Mizala y Andrea Repetto

257. Public-Private Partnerships: when and how

Eduardo Engel, Ronald Fischer y Alexander Galetovic

\section{8}

256. Pricing with markups in industries with increasing marginal costs

José R. Correa, Nicolás Figueroa y Nicolás E. Stier-Moses

255. Implementation with renegotiation when preferences and feasible sets are state dependent Luis Corchón y Matteo Triossi

254. Evaluación de estrategias de desarrollo para alcanzar los objetivos del Milenio en América Latina. El caso de Chile

Raúl O’Ryan, Carlos J. de Miguel y Camilo Lagos

253. Welfare in models of trade with heterogeneous firms Alexandre Janiak

252. Firm-Provided Training and Labor Market Policies Felipe Balmaceda

251. Emerging Markets Variance Shocks: Local or International in Origin? Viviana Fernández y Brian M. Lucey

250. Economic performance, creditor protection and labor inflexibility Ronald Fischer

249. Loyalty inducing programs and competition with homogeneous goods N. Figueroa, R. Fischer y S. Infante

248. Local social capital and geographical mobility. A theory Quentin David, Alexandre Janiak y Etienne Wasmer

* Para ver listado de números anteriores ir a http://www.cea-uchile.cl/. 